\title{
The use of bone grafts in dental practice
}

\author{
El uso de injertos óseos en la práctica dental \\ o uso de enxertos ósseos na prática odontológica
}

\author{
Jefferson David Melo de Matos ${ }^{1}$ \\ Pedro Jacy Santos Diamantino ${ }^{2}$ \\ Renato Sussumu Nishioka ${ }^{3}$ \\ Marco Antonio Bottino ${ }^{4}$ \\ Guilherme da Rocha Scalzer Lopes ${ }^{5}$ \\ Valdir Cabral Andrade ${ }^{6}$
}

Recieved: August 24th, 2018

Approved: May 7th, 2019

Available: July 1th, 2019

How to cite this article: Melo de Matos JD, Santos Diamantino PJ, Nishioka RS, Bottino MA, Scalzer Lopes GR, Cabral Andrade V. The use of bone grafts in dental practice. Rev Nac Odontol. 2019;15(29):1-11. doi: https://doi.org/10.16925/2357-4607.2019.02.09

Literature Review Article https://doi.org/10.16925/2357-4607.2019.02.09

1 Autor de correspondencia: Jefferson David Melo de Matos D.D.S.; M.D.; Ph.D Student. Post Graduate Student - Ph.D Program, Department of Dental Materials and Prosthodontics, São Paulo State University (Unesp), Institute of Science and Technology, São José dos Campos - SP.

Avenida Engenheiro Francisco José Longo, 777/778, Jardim São Dimas, São José dos Campos SP, CEP. 12245000.Phone: +55 (88) 99603-9595.

E-mail: matosjefferson19@gmail.com

2 Universidade Estadual Paulista (UNESP), Instituto de Ciência e Tecnologia, São José dos Campos - São Paulo, Brazil

ORCID: https://orcid.org/0000-0001-9951-9045

3 Universidade Estadual Paulista Júlio de Mesquita Filho (UNESP), Instituto de Ciência e Tecnologia, São José dos Campos - São Paulo, Brazil

ORCID: https://orcid.org/0000-0001-6533-208X

4 Universidade Estadual Paulista (UNESP), Instituto de Ciência e Tecnologia, São José dos Campos - São Paulo, Brazil

ORCID: http://orcid.org/0000-0003-0077-3161

5 Universidade Estadual Paulista (UNESP), Instituto de Ciência e Tecnologia, São José dos Campos - São Paulo, Brazil

ORCID: https://orcid.org/0000-0002-4310-0082

6 Universidade Federal de Juiz de Fora UFJF, Governador Valadares - Minas Gerais, Brazil ORCID: https://orcid.org/0000-0002-1680-2855 


\begin{abstract}
Introduction: The aim of this study is to describe, via literature review, the use of bone grafts and the types most commonly used to rebuild following alveolar bone loss.

Methodology: This literature review was conducted using the following databases: Pubmed (https://www.ncbi. nlm.nih.gov/pubmed), Scielo (http://www.scielo.org/php/index.php). The keywords for the textual search were: Bone Regeneration, Alveolar Bone Grafting, Dental Research, Dentistry. The inclusion criteria were: Literature that covers the subject under study, Literature of the last five years (from 2014 until 2019), English Language, systematic review, laboratory and clinical studies. The exclusion criteria were: literature review, letter to the editor, opinion article, literature duplicated in databases and literature that did not address the variables under study.

Literature Review: 186 articles were found, but according to the inclusion criteria, only 30 were selected for this study. Bone is a specialized, vascularized and dynamic connective tissue that changes over the life of the organism. When injured, it has a unique capacity for regeneration and repair without the presence of scars, but in some situations due to the defect size, the bone tissue does not regenerate completely; thus, it is necessary to perform bone grafting procedures.

Conclusion: The use of bone grafts in dentistry is shown to be a very effective and useful resource considering its great applicability in bone reconstructions in various areas of dentistry. However, greater knowledge about the viability and influence of biomaterials on bone repair, whether associated with autogenous grafts or not, is necessary.
\end{abstract}

Keywords: Bone Regeneration; Alveolar Bone Grafting; Dental Research; Dentistry.

\title{
Resumen
}

Introducción: el objetivo de este artículo es describir, mediante una revisión de la literatura, el uso de injertos óseos y los tipos más utilizado para reconstruir después de la pérdida ósea alveolar.

Metodología: Esta revisión de la literatura se realizó utilizando las siguientes bases de datos: Pubmed (https: //www.ncbi.nlm.nih.gov/pubmed), Scielo (http://www.scielo.org/php/index.php). Las palabras clave para la búsqueda textual fueron: Regeneración ósea; Injerto de hueso alveolar; Investigación dental; Odontología. Los criterios de inclusión fueron: literatura que cubre el tema en estudio, Literatura de los últimos cinco años (desde 2014 hasta 2019), Idioma inglés, revisión sistemática, laboratorio y estudios clínicos. Los criterios de exclusión fueron: revisión de la literatura, carta al editor, artículo de opinión, literatura duplicada en bases de datos y literatura que no aborda las variables bajo estudiar.

Revisión de la literatura: se encontraron 186 artículos, pero de acuerdo con los criterios de inclusión, solo 30 fueron seleccionados para este estudio. El hueso es un tejido conectivo especializado, vascularizado y dinámico que cambia durante la vida del organismo. Cuando se lesiona, tiene una capacidad única de regeneración y reparación sin la presencia de cicatrices, pero, en algunas situaciones, debido al tamaño del defecto, el tejido óseo no se regenera por completo; por lo tanto, es necesario para realizar procedimientos de injerto óseo.

Conclusión: El uso de injertos óseos en odontología se muestra como un recurso muy efectivo y útil considerando su gran aplicabilidad en reconstrucciones óseas en diversas áreas de la odontología. Sin embargo, mayor conocimiento sobre la viabilidad e influencia de los biomateriales, asociados o no a injertos autógenos, en la reparación ósea es necesario.

Palabras clave: regeneración ósea; injerto de hueso alveolar; investigación dental; odontología. 


\section{Resumo}

Introdução: o objetivo deste artigo é descrever, através de uma revisão da literatura, o uso de enxertos ósseos e os tipos mais utilizados para reconstruir após perda óssea alveolar.

Metodologia: Esta revisão de literatura foi realizada utilizando os seguintes bancos de dados: Pubmed (https: //www.ncbi.nlm.nih.gov/pubmed), Scielo (http://www.scielo.org/php/index.php). As palavras-chave para a pesquisa textual foram: Regeneração óssea; Enxerto ósseo alveolar; Pesquisa odontológica; Odontologia. Os critérios de inclusão foram: literatura cobrindo o assunto em estudo, literatura dos últimos cinco anos (de 2014 a 2019), idioma inglês, revisão sistemática, estudos laboratoriais e clínicos. Os critérios de exclusão foram: revisão da literatura, carta ao editor, artigo de opinião, literatura duplicada em bancos de dados e literatura que não trata de variáveis sob estudo.

Revisão da literatura: foram encontrados 186 artigos, mas de acordo com os critérios de inclusão, apenas 30 foram selecionados para este estudo. 0 osso é um tecido conjuntivo especializado, vascularizado e dinâmico que muda durante a vida do organismo. Quando ferido, possui uma capacidade única de regenerar e reparar sem a presença de cicatrizes, mas, em algumas situações, devido ao tamanho do defeito, o tecido ósseo não se regenera completamente; portanto é necessário realizar procedimentos de enxerto ósseo.

Conclusão: 0 uso de enxertos ósseos em odontologia é mostrado como um recurso muito eficaz e útil, considerando sua grande aplicabilidade em reconstruções ósseas em diversas áreas da odontologia. No entanto, mais conhecimento sobre a viabilidade e influência de biomateriais, associados ou não a enxertos autógenos, no reparo ósseo é necessário.

Palavras-chave: regeneração óssea; enxerto ósseo alveolar; pesquisa odontológica; odontologia

\section{Introduction}

Bone is a specialized, vascularized and dynamic connective tissue that changes over the life of the organism (1). When injured, it has a unique capacity for regeneration and repair without the presence of scars, but in some situations due to the defect size, the bone tissue does not regenerate completely; thus, it is necessary to perform bone grafting procedures (2).

Bone is a plastic structure formed by calcium phosphate crystals in the form of hydroxyapatite seated in an organized collagen matrix and, throughout the life of the individual, constantly remodels itself with the purpose of maintaining its mechanical properties and its correct metabolism ((3). Formed of cells, the bone also assumes the role of a tissue, with these cells being responsible for the remodeling and repair of this tissue, forming new bone (4).

The cells responsible for this remodeling live in equilibrium and metabolic harmony, that is to say, as a part of the bone tissue is absorbed by the bone cells specialized in resorption (osteoclasts), a new bone matrix is formed by the cells specialized in renewal of the bone matrix by deposition of calcium and crystals of hydroxyapatite (osteoblasts) (5). 
Of all bone tissue that compound an individual, the bone structure with the most rapid remodeling metabolism is that found in the jaws, so currently the major defects and advanced resorption (pathological or physiological) affect many dentistry treatment, mainly dental implant rehablititations (6). Most of the cases of bone loss in this region are the result of pathological consequences, traumatic treatments and oral diseases from dentoalveolar traumatisms, dental extractions, pathologies involving maxilla and mandible, periodontal diseases and traumatic surgeries (7).

Bone has, in essence, a great regenerative capacity and for this reason, many dental specialties in their treatments for patients who have suffered great resorptions (especially of the alveolar ridge) currently use bone graft techniques (8). In oral and maxillofacial surgery, bone is the most commonly required tissue, as well as in preprosthetic surgeries in the treatment of congenital defects and dentofacial deformities (9).

The aim of the present study was to describe, through a review of the literature, the use of bone grafts and the most commonly used grafts in contemporary dentistry.

\section{Methods}

This literature review was conducted using the following databases: Pubmed (https:// www.ncbi.nlm.nih.gov/pubmed), Scielo (http://www.scielo.org/php/index.php). The keywords for the textual search were: Bone Regeneration, Alveolar Bone Grafting, Dental Research, Dentistry. A total of 186 articles were found but only 30 fit with the inclusion criteria, being: Literature that covers the subject under study, Literature of the last five years (from 2014 until 2019), English Language, systematic review, laboratory and clinical studies. The exclusion criteria were: literature review, letter to the editor, opinion article, literature duplicated in databases and literature that did not address the variables under study (Figure 1). 


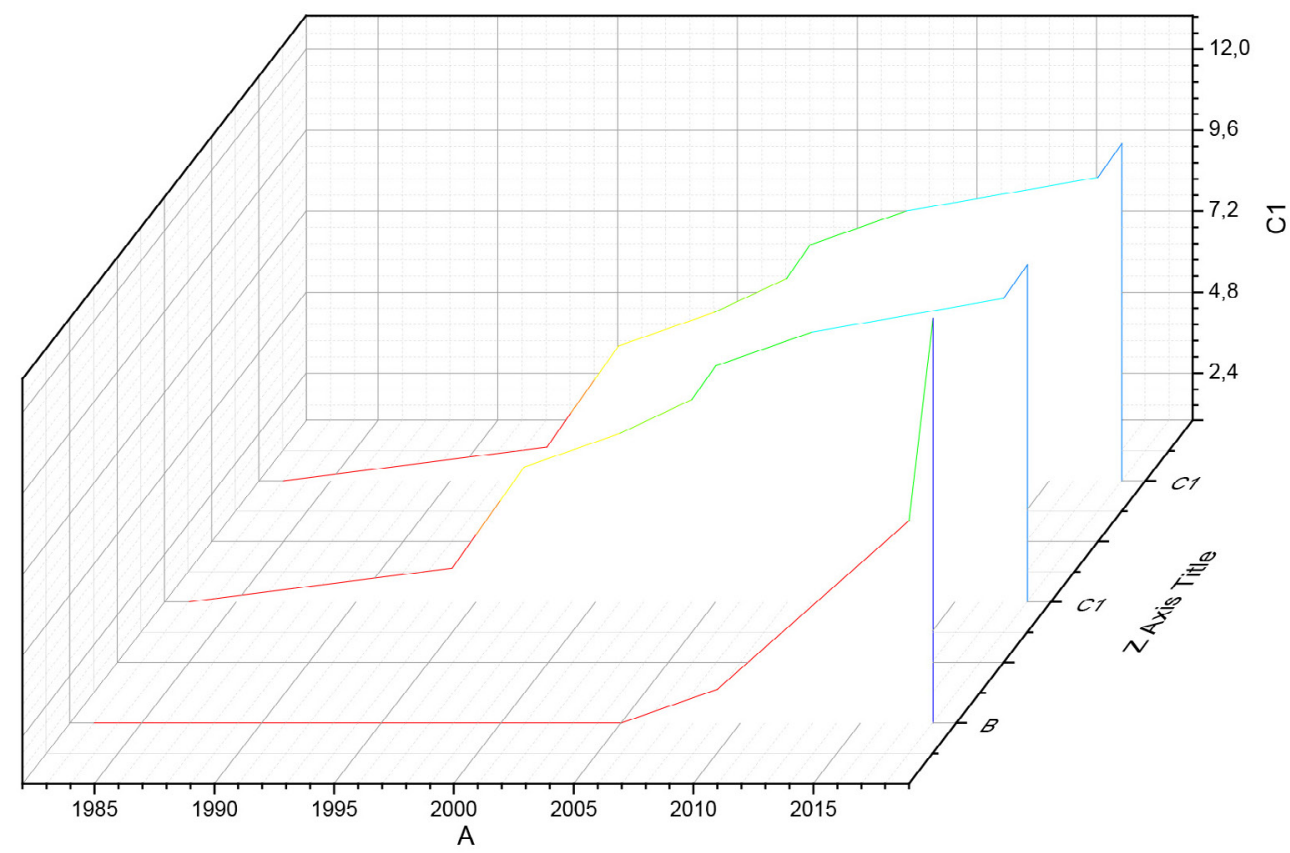

Figure 1. Diagram showing the increasing number of published articles per year regarding the use of bone grafts.

Source: own work

\section{Literature Review}

Bone grafts are made of biomaterials derived from a variety of sources. Currently, there are a large number of biomaterials available to rebuild alveolar bone structures, which are classified as: 'autogenous bone' when it comes from the individual; 'allografts' when obtained from another individual of the same species; 'alloplastic materials' may be of a metallic, ceramic or polymeric nature; 'xenografts' obtained from individuals of species other than the recipient (usually bovine) (10). Bone grafts also have some capacities that are beneficial towards the organism, which are: 'osteogenic properties' that refers to the ability of the biomaterial to carry viable cells; 'osteoconductive properties' that refers to the ability of the biomaterial to induce undifferentiated mesenchymal cells from the own bone and differentiate them into osteoblasts and osteoclastos; 'osteoconductive properties' that refers to the ability of the biomaterial to act as a framework for bone neoformation, allowing cell migration and proliferation of blood vessels into the biomaterial (11). 
Autogenous materials are considered to be the most easily tolerated by adjacent tissues; in cases that present a need for bone replacement, different options may be used, such as autologous bone or allografts bone marrow, demineralized bone matrix, a calcium phosphate bone base, among others (12). The bone undergoes formation from biological processes, thus promoting its regeneration and neoformation by three mechanisms: 'osteogenesis' in which transplanted cells replicate and form a new osteoid (with larger quantities of transplanted cells generating a greater resistance to the grafting procedure but providing higher rates of bone regeneration) (13); 'osteoinduction' is the formation of bone tissue starting from the differentiation of connective fibroblast tissue into osteoblasts, cells responsible for bone deposition; 'osteoconduction' process of growth of progenitor bone cells and capillaries (14).

Considering that bone grafts serve both as a mechanical support (osteoconduction) and as a source of osteogenesis and osteoinduction, the clinical success of this procedure depends on the knowledge of the biological principles of bone repair, not forgetting surgical technique and adequate manipulation of the graft (15). Considered as the best choice, the autogenous graft provides living cells, essential for the osteogenesis phase, where bone cell proliferation occurs; the more cells that are transplanted, the more bone will be formed (16).

Autogenous grafts can be obtained from extraoral donor sites: the crest of the iliac bone (spongy-medullary bone grafts), skull cap, tibia, ribs and intraoral donor sites (especially for smaller grafts) being the most frequently chosen areas (17). Obtaining autografts is sometimes a slightly morbid affair, particularly in cases concerning children, where the amount of graft material is often insufficient. The lack of adequate quantities of bone to fill large defects has therefore increased the use of fresh and frozen bone allografts, for which there is still no satisfactory and sufficient synthetic substitute (18).

The bone for graft in the maxilla and mandible areas are most often obtained from the patient, removed from the chin where there are no noble structures to be damaged by the process of obtaining of this bone. When the amount of this biomaterial is not sufficient to cover the entire grafted area, it is necessary to obtain material previously stored in bone banks (19).

Obtention of the majority of frozen bone allografts is from individuals who underwent cardiac arrest under strict aseptic techniques, with the removal of radius, ulna, femur, tibia, and fibula; the techniques for obtaining bone tissues for storage in the bone banks are highly regulated (as they should be) (20). Samples with Swab on Stuart's medium are sent to laboratories for bacteriological testing. The bones are immersed in $10 \%$ glycerol cryoprotective solution where they remain for 30 minutes. 
Subsequently, they are packaged separately in two colorless, transparent, flexible, odorless and sterile polyamide double bags (one inside the other) and sealed with a suitable sealant (21). The femur, knee and iliac are used, with it being possible to remove the humerus, ribs and long bones in general. After removal of the bones, all soft parts, muscle insertions and periosteum are cleaned. Then the lavage is performed with saline and gentamicin (80mg for every $500 \mathrm{ml}$ of saline solution) and the bone is placed in a sterile plastic container, hermetically sealed, where it is maintained at a temperature of about $-4^{\circ} \mathrm{F}$ in a conventional freezer. At that temperature, the enzymes present in the tissue are still active and will eventually destroy the tissue. Each stored bone is $\mathrm{x}$-rayed to rule out lesions and bone tumors or even metastases from other neoplasms. Finally, files containing the characteristics of each bone as well as the treatments to which it was submitted are completed, along with a record containing data from the donor's registry and stating the bones removed (22).

In the last five years, numerous amounts of research have been published on the use of bone grafts in the dental area, thus, there is a growing interest in the subject (Figure 1) (23-25). There are many specialties that use bone grafts, with Implant Dentistry being one of them. This is an area in which aesthetic-functional rehabilitation, through safe and predictable techniques, returns a correct and satisfactory capacity for mastication to the patient (26). When the patient does not have enough bone to adapt the implants to their alveolar ridge (in function of dental extractions and consequent atrophy of this ridge), it may be difficult or even impossible to rehabilitate through the use of dental implants, making it necessary to rebuild the bone loss. This process is facilitated by bone allografts. Apical surgery, periodontal regeneration, orthognathic surgery, maxillary sinus lift and atrophic alveolar ridge reconstruction represent some indications for the use of homologous bone grafts in dentistry (27).

Hardin (1994) provides data in his work showing that $30 \%$ of bone grafts in the world are performed in dentistry and that as of the year 1972, 100 thousand cases of bone transplants had been registered; 250 thousand bone transplants had been performed worldwide by 1991 and 150 thousand transplants had been performed in the United States by 2008 (28).

The resorption of the alveolar ridge after an exodontia is a constant alteration; the reason for this occurrence is because the function of the alveolar ridge is to support the teeth; when these are not present in the oral cavity, the bone loses its function and tends to reabsorb gradually (29). Buccal alveolar bone resorption after tooth loss is chronic, progressive and irreversible with its greatest progression during the first six months; some patients present a resorption of alveolar bone so intense that they cause atrophy of the jaws. Periodontal disease, trauma, pathological destruction 
and malformations are some other factors that may hinder the rehabilitation of the stomatognathic system with implants. Autogenous bone grafts are currently the treatment of choice for patients with insufficient bone quantity to be rehabilitated with dental implants (30).

\section{Final considerations}

It can be concluded from this study that the use of bone grafts in dentistry is shown a very effective and useful resource considering its great applicability when regenerating alveolar bone loss. However, greater knowledge about the viability and influence of autogenous and autologous bone grafts on bone repair is necessary. Therefore, studies have be done to obtain a synthetic material that is compatible with bone tissue in adequate quantities without the need for extraoral surgeries.

\section{Conflicts of interest}

The authors declare that there are no conflicts of interest.

\section{References}

1. Abuohashish H, Al-Mahalawy H, Zakaria O, Marei H, Abdelhady A, AlKindi M, et al. Delayed Healing of Tooth Extraction Sockets After Vascular Endothelial Growth Factor Inhibition by Bevacizumab. J Oral Maxillofac Surg. 2019; 12(19): 30383-0. pii: S0278-2391(19)303 doi: 10.1016/j.joms.2019.04.003

2. Tsatalis AE, Watanabe K, Mitchell B, Kim DG, Lee DJ, Zheng F, et al. Mechanical and clinical evaluation of the effect of microscrew on root proximity and cortical bone thickness. Eur J Orthod. 2019; 10(17): 1-17. pii: cjz017. doi: 10.1093/ejo/cjz017.

3. Yu N, Nguyen T, Cho YD, Kavanagh NM, Ghassib I, Giannobile WV. Personalized scaffolding technologies for alveolar bone regenerative medicine. Orthod Craniofac Res. 2019; 22(1): 6975. doi: 10.1111/ocr.12275.

4. Qiryaqoz Z, Timilsina S, Czarnowski D, Krebsbach PH, Villa-Diaz LG. Identification of biomarkers indicative of functional skeletal stem cells. Orthod Craniofac Res. 2019; 22 (1): 192-198. doi: 10.1111/ocr.12260. 
5. Lee DJ, Kwon J, Kim Yl, Wang X, Wu TJ, Lee YT, et al. Effect of pore size in bone regeneration using polydopamine-laced hydroxyapatite collagen calcium silicate scaffolds fabricated by 3D mould printing technology. Orthod Craniofac Res. 2019; 22(1): 127-133. doi: 10.1111/ ocr.12261.

6. Zakaria O, Madi M, Kasugai S. Introduction of a novel guided bone regeneration memory shape based device. J Biomed Mater Res B Appl Biomater. 2019; (8)3: 1-7. doi: 10.1002/ jbm.b.34402.

7. Venkatesan N, Thilanga Liyanage AD, Castro-Núñez J, Asafo-Adjei T, Cunningham LL, Dziubla TD, et al. Biodegradable Polymerized Simvastatin Stimulates Bone Formation. Acta Biomater. 2019; 2(19):54-9. pii: S1742-7061(19)30302-2. doi: 10.1016/j.actbio.2019.04.059.

8. Jian B, Wu W, Song Y, Tan N, Ma C. Microporous elastomeric membranes fabricated with polyglycerol sebacate improved guided bone regeneration in a rabbit model. Int J Nanomedicine. 2019; 15(14): 2683-2692. doi: 10.2147/IJN.S192167.

9. Khalil NM, Noureldin MG. Comparison of Single Versus Multiple Low-Level Laser Applications on Bone Formation in Extraction Socket Healing in Rabbits (Histologic and Histomorphometric Study). J Oral Maxillofac Surg. 2019;5(19):363-365. pii: S0278-2391(19)30363-5. doi: 10.1016/j. joms.2019.03.037.

10. Shamsoddin E, Houshmand B, Golabgiran M. Biomaterial selection for bone augmentation in implant dentistry: A systematic review. J Adv Pharm Technol Res. 2019; 10(2): 46-50. doi: 10.4103/japtr.JAPTR_327_18.

11. Jepsen S, Schwarz F, Cordaro L, Derks J, Hämmerle CHF, Heitz-Mayfield LJ, et al. Regeneration Of Alveolar Ridge Defects. Consensus report of group 4 of the 15th European Workshop on Periodontology on Bone Regeneration. J Clin Periodontol. 2019; 30(11): 121-131. doi: 10.1111/ jсpe.13121.

12. Jing D, Yi Y, Luo W, Zhang S, Yuan Q, Wang J, et al. Tissue Clearing and Its Application to Bone and Dental Tissues. J Dent Res. 2019; 98(6): 621-631. doi: 10.1177/0022034519844510.

13. Hosseinpour S, Fekrazad R, Arany PR, Ye Q. Molecular impacts of photobiomodulation on bone regeneration: A systematic review. Prog Biophys Mol Biol. 2019; 17(19): 317-330. pii: S0079-6107(19)30017-3. doi: 10.1016/j.pbiomolbio.2019.04.005. 
14. Wubneh A, Tsekoura EK, Ayranci C, Uludağ H. Current state of fabrication technologies and materials for bone tissue engineering. Acta Biomater. 2018; 15(80): 1-30. doi: 10.1016/j. actbio.2018.09.031.

15. Lima JFM, Matos JDM, Santos JPS, Oliveira AJAG, Vasconcelos JEL, Zogheib LV, et al. Maxillary sinus lift surgery techniques: A literature review. Int J Adv Res. 2017; 5(8): 832-844. doi: 10.21474/IJAR01/5126

16. Santos IKS, Matos JDM, Júnior CUFS, Oliveira AJAG, Franco JMPL, Vasconcelos BCG, et al. Surgery of the maxillary sinus with piezocirurgic system use: Case report. Int J Inf Res Rev. 2017; 4(6): 4258-4260.

17. Pereira ALC, Matos JDM, Cavalcante-Pereira N, Franco JMPL, Vasconcelos BCG, et al. Maxillary Sinus lift and use of L-PRF with a delayed installation of implants-Case report. Int J Dev Res. 2017; 7(6): 13174-13177.

18. Matos JDM, Santos IKS, Perreira ALC, Oliveira AJAG, Vasconcelos BCG, Pita Neto IC, et al. The use of the rich fibrin in platelets and leukocytes as alternative treatment for lifting the maxiIlary sinus - A literature review. Int J Dev Res. 2017; 7(6): 13436-13441.

19. 19. Proêza AP, Corteletti MM, Balbino HCG, Chiarelli FM, Matos JDM, Lopes GRS. Guided bone regeneration with biomaterial use and reaboresorvable membrane: A case report. Int J Adv Res. 2018; 6(5): 884-890.

20. Van de Vijfeijken SECM, Münker TJAG, Spijker R, Karssemakers LHE, Vandertop WP, Becking AG, et al. CranioSafe Group. Autologous bone is inferior to alloplastic cranioplasties Safety of autograft and allograft materials for cranioplasties, a systematic review. World Neurosurg. 2018; 4(18): 875-878. pii: S1878-8750(18)31147-1. doi: 10.1016/j.wneu.2018.05.

21. Begam H, Nandi SK, Kundu B, Chanda A. Strategies for delivering bone morphogenetic protein for bone healing. Mater Sci Eng C Mater Biol Appl. 2017; 70(1): 856-869. doi: 10.1016/j. msec.2016.09.074

22. Park S, Heo HA, Lee KB, Kim HG, Pyo SW. Improved Bone Regeneration With Multiporous PLGA Scaffold and BMP-2-Transduced Human Adipose-Derived Stem Cells by Cell-Permeable Peptide. Implant Dent. 2017; 26(1): 4-11. doi: 10.1097/ID.0000000000000523.

23. Wang P, Zhao L, Liu J, Weir MD, Zhou X, Xu HH. Bone tissue engineering via nanostructured calcium phosphate biomaterials and stem cells. Bone Res. 2014; 30 (2): 14017. doi: 10.1038/ boneres.2014.17. 
24. Dasmah A, Kashani H, Thor A, Rasmusson L. Integration of fluoridated implants in onlay autogenous bone grafts -an experimental study in the rabbit tibia. J Craniomaxillofac Surg. 2014; 42(6): 796-800. doi: 10.1016/j.jcms.2013.11.014.

25. Lin JD, Lee J, Ozcoban H, Schneider GA, Ho SP. Biomechanical adaptation of the bone-periodontal ligament (PDL)-tooth fibrous joint as a consequence of disease. J Biomech. 2014; 27(9): 2102-14. doi: 10.1016/j.jbiomech.2013.10.059.

26. Yamada Y, Nakamura S, Klein OD, Ito K. Current trends in stem cell therapy for improvement of bone quality. Histol Histopathol. 2014; 29(6):691-7. doi: 10.14670/HH-29.691.

27. Song JM, Lee JY, Kim YD. CBCT Morphologic Analysis of Edentulous Posterior Mandible for Mandibular Body Bone Graft. J Oral Implantol. 2015; 41(4): 477-82. doi: 10.1563/ AAID-JOI-D-13-00215.

28. 28. Lee JH, Park JH, El-Fiqi A, Kim JH, Yun YR, Jang JH, et al. Biointerface control of electrospun fiber scaffolds for bone regeneration: engineered protein link to mineralized surface. Acta Biomater. 2014; 10(6): 2750-61. doi: 10.1016/j.actbio.2014.01.021.

29. 29. Babuccu C, Keklikoğlu N, Baydoğan M, Kaynar A. Cumulative effect of low-level laser therapy and low-intensity pulsed ultrasound on bone repair in rats. Int J Oral Maxillofac Surg. 2014; 43(6): 769-76. doi: 10.1016/j.ijom.2013.12.002.

30. Veis A, Dabarakis N, Koutrogiannis C, Barlas I, Petsa E, Romanos G. Evaluation of Vertical Bone Regeneration Using Block and Particulate Forms of Bio-Oss Bone Graft: A Histologic Study in the Rabbit Mandible. J Oral Implantol. 2015; 41(3): 66-72. doi: 10.1563/AAID-JOI-D-13-00241. 